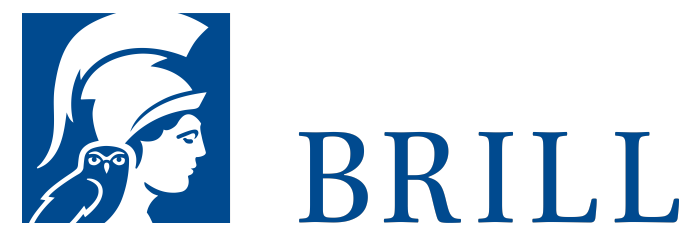

\title{
Stil und Individualität
}

Die Ästhetik gesellschaftlicher Selbstbehauptung

Author: Michael R. Müller

Getreu der Hofmannsthal-Devise, das Tiefe finde sich an der Oberfläche versteckt, thematisiert das Buch die

Selbstdarstellungsaktivitäten dreier Zeitgenossen des 19. Und 20. Jahrhunderts, deren Stile zu einem festen Bestandteil der modernen Muster, Schablonen und Modelle für Individualität geworden sind. Beau Brummell, Oscar Wilde, Andy Warhol - in den textilen Verfeinerungen, theatralischen Gesten und seriellen Bildproduktionen dieser Stilbildner spiegelt sich weiniger die Hybris gesellschaftlicher Außenseiter als vielmehr ein grundlegendes Lebensproblem des heutigen Individuums: die Suche nach glaubwürdigen Ausdrucksformen für jenes gesellschaftlich eingeforderte Maß an persönlicher Souveränität, Kreativität und Unabhängigkeit, das die Pragmatik des gesellschaftlichen Alltagslebens dem einzelnen nur in seltensten Fällen gewährt. Ausgehend von der wissenssoziologisch-sozialanthropologischen Annahme, dass Individualität weder eine moderne Erfindung ist noch ein dem gesellschaftlichen Dasein des einzelnen vorausliegendes Substrat, veranschaulicht das Buch die gesellschaftliche Wandelbarkeit von Individualität: die ideellen Bildentwürfe, denen sie folgt, die Darstellungsästhetiken, in denen sie Gestalt erlangt, und die sichtbaren Widersprüche in die sie gerät, wenn der einzelne sein soll, was er nicht sein kann - eine (Zitat Arnold Gehlen) »Institution in einem Fall «.

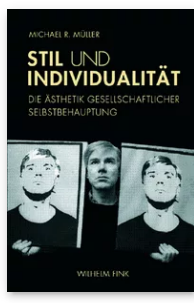

Pages: 263

Seiten, $105 \mathrm{~s} / \mathrm{w}$ Abb.

Language:

German

Subjects:

Cultural History,

Literature and

Cultural Studies

Publisher: Brill |

Fink

E-Book (PDF)

Released online:

og Dec 2019

ISBN: 978-3-

8467-4777-3

List price

USD $\$ 63.00$

Paperback

Publication date: 20 May 2009

ISBN: 978-3-

7705-4777-7

List price

USD $\$ 63.00$ 
For more information see brill.com

Order information: Order online at brill.com +44330 333 0049 | customerservices@brill.com Submission information: brill.com/authors

Titles published by Brill | Fink, Brill | mentis or Brill | Schöningh: +49(o)715413279216| brill@brocom.de 